\title{
Possible impact of COVID-I 9 on senior secondary school students' performance in science education in Nigeria
}

\author{
Oluwatoyin Mary Oyinloye \\ Department of Mathematics, Science and Technology Education, Faculty of Education, University of Zululand, South Africa \\ Correspondences should be addressed to Oluwatoyin Mary Oyinloye iD mooyinloye@yahoo.com \\ Received 25 July 2020; Revised 16 September 2020; Accepted 10 October 2020
}

\begin{abstract}
The recent outbreak of Coronavirus (COVID-19) pandemic has led to the total lockdown of major cities globally which resulted in the early closure of schools in the cities affected, Nigeria inclusive. It is hypothesized that COVID-19 may have a negative outcome on the performance of senior secondary school students in class 3 (SS3) who are yet to write their 2020 external examination (West Africa Senior Secondary Certificate Examination as well as National Examination Council) especially in the science subjects namely Biology, Physics and Chemistry. This study collected data from three teachers who are science experts and head of their respective departments in three government secondary schools in Ado-Ekiti local government area of Ekiti State, Nigeria. A semi-structured interview was used to collect data from the teachers through phone calls and WhatsApp chats. This qualitative study employed a case study research approach. Findings from this study revealed that there is the possibility of a further drop in the pass rate (\%) of senior secondary school students' in this year's external examinations if this pandemic is not contained soon knowing fully well that the school academic calendar has already been disrupted due to early closure of schools in Nigeria. As part of COVID-I9 relief package, recommendations are made to the Federal government of Nigeria and policymakers to distribute iPads and electronic tablets preloaded with e-textbooks in these subject areas to SS3 students and their teachers to facilitate online learning as this will enhance their performance in Science subjects in this year's national examination.
\end{abstract}

Keywords: COVID-19, senior secondary school, performance, science education, Nigeria

\section{Introduction}

Over the years, poverty and malnutrition have been implicated to have a far-reaching consequence on the academic performance of school children globally (Humble \& Dixon, 2017; Sawaya, 2006). Though Nigeria as a country is blessed immensely with extraordinary economic resources such as oil, cocoa, rubber and plantations, however, the country is not spared from the global trends of poverty as accessibility to quality education is a big challenge for the majority of the poor masses in the country (Ismail, 2010). From time immemorial, various governments in Nigeria have launched different Poverty Eradication or Poverty Alleviation schemes to eradicate poverty and malnutrition in the country, but it seems this goodwill of the various governments have become avenues for corrupt politicians to embezzle and gather ill-gotten wealth. Rather than the goodwill improving the lives of the citizen, many are falling into abject poverty. The inability of the citizens to have access to three square meals in a day is a major index revealing poverty in the land. Another index of poverty among the citizens is the inability to afford quality education as most parents are still owing school fees for 2 to 3 terms respectively and many are unable to buy current textbooks for their children or wards in school. (Kudaisi \& Martins, 2014; Ismail, 2010).

Sometimes in 2019, there was an outbreak of a viral disease (Coronavirus: COVID-19) in Wuhan, China. This epidemic recently turned into a ravaging pandemic which posed a serious threat to global public health and eventually led to the total lockdown of major cites globally, Nigeria inclusive (Lin et al., 2020). This pandemic has also led to the early closure of Schools and Citizens have been advised to isolate themselves and maintain social distancing for the fear of been infected by this deadly virus (Sintema, 2020). Towards the end of March 2020, 27th to be precise through the press briefing by the Minister of Health in Nigeria, all institutions cutting across primary, secondary and tertiary institutions were instructed to close down the current academic session, due to the deadly Coronavirus which was ravaging the whole world. The conventional assessment approach adopted by most schools in Nigeria is summative assessments, where teachers teach and then administer tests and examinations to find out what learners have achieved (Oyinloye \& Imenda, 2019). Majority 
of the schools in Nigeria have just concluded their second continuous assessment test and unfortunately, they are not able to write their second term examination before the compulsory closure due to the fear of the spread of COVID-19.

At the moment, not many studies have been carried out on the impact of COVID-19 concerning students' achievement in educational studies. Although there are available data in literature directly related to medical sciences and practices. Regrettably, education will be greatly affected by COVID-I 9 and therefore, the impact of this disease should be incorporated into educational studies for the government at various levels to make adequate provisions for learners and their teachers across the globe (Sintema, 2020). With medical personnel and researchers who are working tirelessly in the laboratory to come up with a curative therapy or a vaccine to combat COVID-19, it is a welcome idea from the government to shut down schools to protect learners from possible risks of contracting COVID-19 due to the daily increase in the number of confirmed cases across the country. However, many low- and middle-income countries are faced with the agony of the devastating effect this pandemic on their economy. In Nigeria, secondary schools are operated in sessions. Each session comprises of three terms, in each of the terms we have up to 13-14 weeks of active teaching and learning. With the present situation of COVID-19 in Nigeria, secondary schools are under lock and key. Students' effort and preparation towards their examination have been adversely affected by this global pandemic which has forced everyone into unprepared self-isolation. As of now, Nigeria does not have a welldeveloped e-learning platform for schools that can cushion the effect associated with loss of learning hours. Therefore the impact of this pandemic will be strongly felt more by the SS3 candidates whose national examination comes up later in the year due to the loss of contact hours (Sintema \& Phiri, 2018). Existing records from a study conducted by Sakiyo and Badau revealed that there was an undesirable trend in the performance of students that wrote Physics, Chemistry and Biology in WASSCE from 2008 to 2012 in Nigeria. Their average performances were $56.01 \%$ in Physics, $46.30 \%$ in Chemistry and $37.27 \%$ in Biology, in addition to an increasing failure rate in Biology and Chemistry (Sakiyo \& Badau, 2015).

Another study carried out by Badmus and Omosewo shows that in recent years, students perform poorly generally in national examinations and most especially in science subjects (Biology, Chemistry and Physics) as presented on Table I (Badmus \& Omosewo, 2018). To this end, little has been said on the potential impact of COVID-19 on the educational sector in Nigeria, especially its effects on the performance of senior secondary school students who will be sitting for the national examinations (West Africa Senior Secondary Certificate Examination as well as National Examination Council). The present situation calls for urgent intervention as these are core subjects which are required for admission into tertiary institutions. Hence, the purpose of this study is to evaluate the possible impact of COVID-19 on SS3 students' performance in science subjects.

Table I

Students' Enrolment and Performance in West Africa Senior Secondary Council Examination (WASSCE) in science subjects: $2007-2016$

\begin{tabular}{lllllll}
\hline \multicolumn{2}{c}{ Biology } & \multicolumn{2}{c}{ Chemistry } & \multicolumn{2}{c}{ Physics } \\
\hline Year & $\begin{array}{l}\text { Number of } \\
\text { Students }\end{array}$ & $\begin{array}{l}\text { Percentage } \\
\text { (\%) pass }\end{array}$ & $\begin{array}{l}\text { Number of } \\
\text { Students }\end{array}$ & $\begin{array}{l}\text { Percentage } \\
\text { (\%) pass }\end{array}$ & $\begin{array}{l}\text { Number of } \\
\text { Students }\end{array}$ & $\begin{array}{l}\text { Percentage } \\
\text { (\%) pass }\end{array}$ \\
\hline 2007 & $1,238,163$ & 33.37 & 196,063 & 46.16 & 409,063 & 44.16 \\
\hline 2008 & $1,259,964$ & 33.94 & 202,762 & 44.37 & 408,237 & 49.08 \\
\hline 2009 & $1,259,964$ & 33.87 & 203,762 & 43.49 & 444,236 & 50.14 \\
\hline 2010 & $1,300,418$ & 32.88 & 263,059 & 50.70 & 463,755 & 51.27 \\
\hline 2011 & $1,505,199$ & 38.50 & 280,250 & 49.54 & 563,161 & 63.94 \\
\hline 2012 & $1,646,150$ & 35.66 & 270,570 & 43.13 & 624,658 & 68.74 \\
\hline 2013 & $1,648,363$ & 51.73 & 462,517 & 72.34 & 637,023 & 46.77 \\
\hline 2014 & $1,365,384$ & 56.17 & 397,649 & 62.49 & 635,729 & 60.76 \\
\hline 2015 & $1,390,234$ & 57.42 & 412,323 & 60.60 & 684,124 & 60.01 \\
\hline 2016 & $1,200,367$ & 61.68 & 408,122 & 57.74 & 705,125 & 58.95 \\
\hline
\end{tabular}

Source: Badmus \& Omosewo, 2018 [Statistics Section of the WAEC Office Yaba, Lagos (2017)] 


\section{Method}

\section{I. Research Design and Participants}

This qualitative research approach employed Case Study. Case studies are in-depth investigations into specific and relatively smaller areas of interest and are constructions that use the conventions of narrative to insightfully explore issues with which the researcher has intellectually wrestled with (Starman, 20I3). The research was conducted with the participation of three teachers. While one of these teachers is employed at the biology, the other two are from the physics and chemistry. They also served as data sources by reflecting and sharing their views with the researcher through phone calls and WhatsApp chats used for the interviews.

\subsection{Instrument}

A semi-structured interview data collection instrument (Patton, 2002) was used to gain insight into how the science teachers perceived the occurrence of COVID-19 and its possible impact on the performance of the senior secondary students by allowing them to provide deep descriptions of their views. Semi-structured formats assume that individual respondents define the issues in unique ways. Teachers' interview questionnaires were adopted by the researcher (Sintema, 2020) to reveal teachers' views about COVID-19. The teachers' interview instrument consisted of five questions. Because of cross-cultural differences between countries, an expert in test and measurements has ascertained both the face and content validity of the instrument before it's administration to the participating teachers.

\subsection{Data Collection}

Semi-structured Interviews were conducted through phone calls because there was a nation-wide lockdown and a call for self-isolation and social distancing by all citizens. The telephone interviews were recorded using a phone call recording application which was downloaded from play store of the Android phone which was used for this study. The average time spent on phone interviews was about thirty minutes.

\subsection{Data Analysis}

The data collected through the semi-structured interview from teachers were analyzed qualitatively, searching for themes that emerged from the data (Mogalakwe, 2006; Alhojailan, 2012; Isaacs, 20I4). This analysis focused on discovering and describing the breadth of various perceptions held by the respondents. The data were transcribed and analysed using thematic qualitative data analysis techniques. Transcription and coding of data were performed by the researcher. All forms of inconsistencies and discrepancies were discussed and harmonized.

\section{Results}

The three teachers expressed their views on the possible negative impact of COVID-19 on student performance in the forthcoming external examinations, which is likely to be caused as a result of loss of contact hours by students. As a result of the pandemic, students no longer have any contact with their teachers for any consultation during their reading, the impact of this is felt majorly $\mathrm{n}$ the area of practicals which is the backbone of most science subjects. These the teachers acknowledged was going to probably result in the drop likely to be seen in the students' performances in their external examinations. Below are some of the teachers' responses.

With the present situation in the country, all students will be adversely affected especially the senior secondary school (SS3) who were at the verge of writing external examination in May/June. By now they should be writing their practical and in full preparation for their main examination (SSCE). Rather, they are still in self-isolation with the fear of been infected with the virus (TI).

Some of these (SS3) students came from both rural and urban areas where some of them may not have access to any facility during this lockdown for them to be able to connect with any program online. Majority of the students are deprived of necessary basic amenities that could facilitate learning (T2). 
Students preparing for (SSCE) were usually assisted by teachers by organising extra lessons for them either early in the morning or weekend to finish the syllabus but with the daily increase in the number of new cases in the country and the on-going self-isolation which has prevented teachers from teaching, the external examination may be postponed (T3)

When the three teachers where asked if the (SS3) students whose examinations usually come up in May/June will be affected, the teachers emphatically stated that the effect had already started with non-administration of second term examination as a result of the sudden closure of schools.

Before the closure of schools, students were encouraged and motivated to study hard and prepare well for their forthcoming second term examination which comes up in two weeks, an event which never took place. When these students received the news that school is about to be closed, they were disturbed psychologically which also affected their preparation towards their examination. As regard studying, students seem to study well when they see their counterpart reading either in the library or in the class during their free period and are able to ask questions from their peers and teachers on areas they find challenging. However, with the present lockdown of schools, it will be difficult for students to get clarity to areas of needs from teachers during personal study time (TI).

The science teachers who were interviewed also stated the effect of this pandemic on the students bearing in mind their different abilities as regard teaching and learning. The issue of individual differences in terms of their intelligent quotient (IQ) and rate of understanding and learning differs from one student to the other as well as the strategies employed by teachers to impart knowledge and to prepare them for external examination.

There is no gainsaying that the SS3 students will be affected adversely due to the loss of contact hour of teaching, these students possess different learning abilities which make some fast learners and some slow learners. The fast learners can read and study on their own with little or no help, they comprehend easily and learn fast while the slow learners often depend on the teacher to explain the concept been taught. With the closure of school, majority of students are now at home and some of them have abandoned their books thinking that the national examination will be postponed. With the situation of things on ground, teachers may be forced to go on a crash program to cover up the syllabus with the students as soon as the lockdown is lifted (T2).

These teachers expressed their potential fear on the forthcoming external examination (SSCE) result and they emphasized the possibility of a drop in student performance in this year's examination due to the COVID-19 pandemic. Although, they are hopeful that by the end of July the virus should have been contained.

One of the teachers said she may not be able to state accurately the extent of the possible impact COVID-19 may have on students' performance in this year national examination. Although some states have organised school in the air to cushion the effect of loss of contact hours in school. However, we live in a country where there is no stable electricity for students to watch television. What becomes of these students after COVID-19 curve is flattened? I am not sure if they will be able to cope with the numerous workload they will be burdened with. Also, the s teachers will undergo lots of stress in order to cover up their schemes of work before the commencement of the national examination (TI, T2 \& T3).

Some of the factors which the teachers highlighted could affect the performances of the students include the issue of power failure in the country and the lack of necessary facilities which are absent in Nigeria schools coupled with the pandemic. Also, considering the fact that previous results have not been encouraging especially in Biology, Physics and Chemistry, COVID-19 health issues are expected to hinder good performance in external examination.

Presently, we believe that the Ministry of Education should come up with a re-schedule of West Africa Senior Secondary Certificate Examination (WASSCE) timetable and give an appropriate intervention/strategies to be used in teaching in order to cover the syllabus. Also, the long vacation holiday should be shortened for other classes to commence the third term on time. If teachers handling exam classes will be motivated and 
encouraged, they will be teaching the students early in the morning and weekend to alleviate the effect of the lost time (TI, T2 \&T3).

The Physics and Chemistry teacher were of the opinion that the free periods on their school timetable can be used for more practical classes. While the Biology teacher said since Biology is one of the science subject offered by all students in the senior class and is usually a large class she is going to employ an interactive intervention for teaching ( $T I, T 2, \& T 3)$.

These three teachers in the course of the interview had a common opinion that with the occurrence of COVID-I9 in our nation, the longer it stays the more damaging its impact would be on our education system.

\section{Discussion}

Many educational institutions globally are currently adopting new strategies for teaching and learning as various digital online platforms are being adopted to replace the physical classroom since schools are under lock and key (Mulenga \& Marbán, 2020). The results of this study specify that COVID-I 9 will have a negative impact on the education system in Nigeria, due to the effect of lost in contact hours as a result of early closure of schools across the Nation. Majority of the schools in Nigeria lack e-learning facilities to enable teachers interact with their students at such a time as this, even the few schools that have such facilities, majority of the students are unable to access it as a result of epileptic power supply. It has also been pointed out in this study that if COVID-19 is not contained soon, it could destabilise the graduating classes especially the SS3 students and result in mass failure in science subjects in this year's West Africa Senior Secondary Certificate Examination (WASSCE).

Added to this, the results shows that teachers are getting prepared to teach with new instructional strategies in order to minimise the effect COVID-19 may pose on students' performance in the national examination as soon as the COVID-19 curve is flattened. However, the teachers who took part in this study expressed their concern about the lack of e-learning facilities in their schools and they also complained about instability and consistent power failure in the country. They acknowledged that stable electricity in Nigeria will facilitate elearning by allowing teachers to continue teaching and even conduct alternatives to practical classes. They believe this would increase students' performance in no small measure in their forthcoming examination.

In addition to the aforementioned, many of the parents who are civil servants (working with the government) have not been paid their salary while the majority of those working with the private establishment are been laid-off due to the devastating results and negative economic impact caused by COVID-19 pandemic. This has contributed in no small measure to poverty. Therefore, it is difficult for many parents to feed their family and hence they cannot afford to buy data for the children or ward to participate in online classes and also download educational materials sent to them by their teachers.

\section{I. The implication for Further Studies}

This study has been able to establish the possible effect of COVID-19 on SS3 students who are going to write West Africa Senior Secondary Certificate Examination (WASSCE) this year. It is believed that the result of this study will assist other researchers to investigate other possible issues or areas of interest where COVID-19 might have a damaging effect on the students' ability to learn. Also, this study explained the teachers' opinions and concerns regarding the forthcoming examination which has been postponed until further notice. If COVID-19 pandemic prolongs more than necessary, it could have a deleterious ripple effect on the educational system in Nigeria. Thus, all essential measures should be in place to flatten the curve quickly. As we look up to reopening of our schools very soon, we, therefore, call on the relevant government authority to kindly fund the educational system in Nigeria and also provide necessary types of equipment and tools. Teachers and Students should also be trained to familiarize and equip them with what it takes to teach and learn using innovative strategies in this new era. This training should include how to use the various platforms available for online classes. With this in place, it is believed that we can achieve optimum students' performance in both internal and external examinations. As part of COVID-19 relief package, recommendations are made to the Federal government of Nigeria and policymakers to distribute iPads and 
electronic tablets preloaded with e-textbooks in these subject areas to SS3 students' and their teachers' in order to facilitate online learning as this will enhance their performance in Science subjects in this year's national examination.

\section{Conclusion}

Taken together, this study has demonstrated that COVID-19 will have a negative impact on the educational system in Nigeria notably on the graduating classes especially the SS3 students who will be writing the West Africa Senior Secondary Certificate Examination (WASSCE) this year. We do not know how long is going to take before it clears off from the Nations of the world. We are hopeful that as schools resume soon, teachers will be able to employ different instructional strategies to teach students within the shortest available time.

\section{References}

Alhojailan, M. I. (20I2). Thematic Analysis: A critical Review of its process and Evaluation. West East Journal of Social Science, I (I), 39-47.

Badmus, O. T. \& Omosewo, E. O. (2018). Improving Science Education in Nigeria: The Role of Key Stakeholders. European Journal of Health and Biology Education, 7(I), II-I5. https://doi.org//0.29333/ejhbe/87086

Humble, S. \& Dixon, P. (2017). The effects of schooling, family and poverty on children's attainment, potential and confidence-Evidence from Kinondoni, Dar es Salaam, Tanzania. International Journal of Educational Research, 83, 94-106. https://doi.org/I0.1016/j.ijer.2017.03.00I

Isaacs, A. N. (2014). An overview of qualitative research methodology for public health researchers. International Journal of Medicine and Public Health, 4(4), 3 I8-323. https://doi.org/I 0.4 I03/2230-8598. 144055

Ismail, H.A. (2010). The effect of poverty on education in Nigeria: Obstacles and Solutions. Oida International Journal of Sustainable Development, I (4), 55-72. https://ssrn.com/abstract=I666424

Kudaisi, B.V \& Martins, F.F (20I4). Effects of Poverty on Children Educational Attainment in Isua, Akoko South East Local Government, Ondo State. Research on Humanities and Social Sciences, 4(23), 35-45. https://www.iiste.org/Journals/index.php/RHSS/article/viewFile/I6908/I 7237

Lin, Q., Zhao, S., Gao, D., Lou, Y., Yang, S., Musa, S.S., Wang, M.H., Cai, Y., Wang, W., Yang, L., He, DF. (2020). A conceptual model for the coronavirus disease 2019 (COVID-19) outbreak in Wuhan, China with individual reaction and governmental action. International Journal of Infectious Diseases, 93, 21I-216. https://doi.org/10.1016/j.ijid.202

Mogalakwe, M. (2006). The use of documentary research methods in social research. African Sociological Review, IO(I), 22I-230. https://doi.org/I0.1353/eas.0.0006

Mulenga, E. M., \& Marbán, J. M. (2020). Is COVID-I9 the Gateway for Digital Learning in Mathematics Education?. Contemporary Educational Technology, I2(2), ep269. https://doi.org// 0.30935/cedtech/7949

Oyinloye, O., \& Imenda, S. (2019). The Impact of Assessment for Learning on Learner Performance in Life Science. Eurasia Journal of Mathematics, Science and Technology Education, I5(II), I-8. https://doi.org/I 0.29333/ejmste/I 08689

Patton, M. Q. (2002). Qualitative research and evaluation methods (3rd ed.). Thousand Oaks, CA: Sage publications.

Sakiyo, J. \& Badau, K. M. (20I5). Assessment of the trend of secondary school students' academic performance in the sciences, Mathematics and English: Implications for the attainment of the Millennium Development Goals in Nigeria. Advances in Social Sciences Research Journal, 2(2), 3I-38. https://doi.org//0.14738/assrj.22.805

Sawaya, S. M. (2006). Malnutrition and poor academic performance: critical contributions. Estudos Avançados, 20(58), $133-146$.

Sintema, E. J., \& Phiri, P. A. (2018). An investigation of zambian mathematics student teachers' technological pedagogical content knowledge (TPACK). Journal of Basic and Applied Research International, 24(2), 70-77.

Sintema, E. J. (2020). Effect of COVID-I9 on the Performance of Grade 12 Students: Implications for STEM Education. EURASIA lournal of Mathematics, Science and Technology Education, 16(7), emI85I. https://doi.org//0.29333/ejmste/7893

Starman, A. B. (2013). The case study as a type of qualitative research. Journal of Contemporary Educational Studies/Sodobna Pedagogika, 64(I), 28-43. 